\title{
Internal Audit Functions: An Empirical Study of Public and Private Sectors in Nigeria
}

\author{
Abdulkadir Madawaki ${ }^{* 1}$, Aidi Ahmi ${ }^{2}$ and Halimah @ Nasibah Ahmad ${ }^{2}$ \\ ${ }^{1}$ Department of Accounting, Al-Qalam University Katsina, Nigeria \\ 2 Tunku Puteri Intan Safinaz School of Accountancy, Universiti Utara Malaysia, Malaysia
}

\begin{abstract}
The study examines the similarities and differences between the private and public sectors internal audit functions in Nigeria. The features examined include the hierarchical position of the internal audit functions, outsourcing of internal audit activities, reporting relationship of the internal auditor, and the coordination between internal and external auditors. A survey of internal audit managers of both sectors was undertaken to establish their current practices. The results revealed that there are no much differences in the hierarchical positioning of the internal audit function in both sectors. A substantial difference was found in the reporting lines of internal auditors in both sectors. The results further showed that private sector outsources internal audit activities more than the public sector and a slight difference exists between the two sectors about the level of coordination between internal and external auditors. Finally, the result indicated that private sector experiences a reduction in external audit fees compares to its counterpart in the public sector.
\end{abstract}

Keywords: Internal Audit Function, Private Sector, Public Sector, Comparison, Nigeria.

JEL Classification: M40, M42, M49

Paper Type: Research Paper

\section{INTRODUCTION}

In the last few years, the roles of internal audit function (IAF) in corporate governance have established a growing interest owing to its impact on the internal control risk management system. The internal audit profession has taken advantage of this renewed interest by changing the roles and broadening the scope of internal auditor's participation in the organisational governance process and risk management control. Such

*Corresponding author: E-mail: abdulkadirmadawaki@yahoo.com 
developments have had the goals of expanding the value-adding roles of internal auditors to their organisations.

The increasing roles of internal audit function in both private and public sectors in enhancing corporate governance have been emphasised through various legislations such as the Treadway Commission (1987) and the Cadbury Report (1998). All these were among the first to call for the importance of the internal audit function for adequate internal controls. The importance of internal audit function has increased more after the financial scandals that took place during the last two decades such as Lehman Brothers, WorldCom and Enron which make policymakers more alert on the significance of improving the effectiveness of corporate governance and provided substantial proof on the need for internal audit function as an essential part of effective internal controls.

Based on the notion that good internal audit function is a useful corporate governance mechanism and could result in higher quality governance process in both private and public organisation, this study aims to examine the similarities and differences of internal audit function in the private sector and that of its counterpart in the public sector in Nigeria. Using a survey of internal audit managers of both the private and public sectors organisation in Nigeria to establish the current practices in these organisations the study found that differences exist in both internal audit operations.

The rest of the paper is structured as follows; the next section provides a brief outline of the underpinning theories upon which this study is based. The third section outlines the literature review. The fourth section states the method used, while the results of the study are reported and discussed in the fifth section. Finally, conclusions are drawn, limitations noted and further research opportunities are discussed in the sixth section.

\section{LITERATURE REVIEW}

According to the paradigm of corporate governance developed by the Institute of Internal Auditors (IIA), an effective IAF is one of the four foundations of corporate governance sideways with the management, the board of audit committees and the external auditor (IIA, 2005). Previous literature for example, Paape et al. (2003), Carcello et al. (2005), Sarens (2009) and Soh and Mortinov-Bennie (2011) also uphold the view that IAF is an important corporate governance device that plays a significant role in organizational governance by overseeing the organizational risk, evaluating and assessing control mechanisms.

Prior studies have indicated the existence of disparity between public and private sectors internal audit functions (Carhill \& Kincail 1989; Goodwin 2004). Barac and Steden (2014) in a comparison of public and private sector IAF in South Africa found that internal controls in national departments are recognized to be effective corporate governance mechanisms, but they are not yet well established as those in the public sector.

Studies examining the operational and organizational status of IAF show that James (2002) survey concerning the opinions of bank lending officers about the influence of reporting arrangement on internal audit capabilities to avert financial statement fraud. The findings of the study established that IAF that report to senior management is seen as being less able to avert deceitful financial reporting as against those that report exclusively to the audit committee.

Similarly, Sarens and De Bedde (2006) using a case study method looked at five Belgium companies to examine the expectations of both senior management and internal auditors about the association between the two groups. The study indicated that when internal audit work mainly with a management support role there may be a lack of perceived independence of the internal audit. 
Prior studies have also shown a mixed result about the decision to dismiss the chief internal auditor. For example, Goodwin and Yeo (2001) study the association between IAF and the audit committee influence on the independence and objectivity of the internal auditors. Their result indicated that 72 percent of the audit committee members were involved in the dismissal of the chief internal auditor. In a similar situation, Goodwin (2003) reported that 52 percent of the Australian and New Zealand audit committee members are involved in the decision to dismiss the chief internal auditor.

Outsourcing of internal audit services has become prevalent in recent years. Prior studies have recognized several incentives for outsourcing internal audit services, for example, Caplan and Kirschenheiter (2002) and Abbott et al. (2007). A study of Selim and Yannakas (2002) investigates the manner, and the impact of outsourcing the IAF in the United Kingdom (UK) private and public sector organizations and the impact of outsourcing decision may likely have on auditor independence and quality of audit service. The result of the study indicated that most of the organizations prefer an in-house IAF and that not all respondents are of the opinion that independence may be compromised when internal audit services are outsourced to an external audit.

Carey et al. (2006) examine the causes of internal audit outsourcing in Australian listed firms. The result of the study advocated that internal audit outsourcing is related to perceived cost serving and the technical skills of the external service supplier. Abbott et al. (2007) examine the consequence of SOX as it relates the restriction on outsourcing internal audit services to the external auditor using a sample of 219 responses from 1,000 fortune chief internal auditors. The result of the study indicated that firms with independent, active and expert audit committee are less likely to outsource routine internal audit services to the external auditor

Past studies provide proof of the influence of IAF on audit fees and reliance of external auditors on IAF work (Schneider 1984; AICPA 1990; Felix et al. 2001; Gramling et al. 2004; PCAOB 2007; IFAC 2009; Prawitt et al. 2011; Messier Jr et al. 2011). Felix et al. (2001) and Gramling et al. (2004) reported that increased dependence on the work of the IAF by the external auditor could translate into lower external audit fees. Messier Jr et al. (2011) find that the use of IAF as a management training ground is positively associated with external audit fees. However, Beneish et al. (2006) and Hogan and Wilkins reported an increased in external audit fees as a result of internal control reporting requirements of SOX.

\subsection{Underpinning Theories: Agency and Institutional Theory}

The principal interest of corporate governance stems from the separation of ownership and control in public organizations. Agency theory in this setting present the foundation for explaining the functions assigned to IAF since it is the IAF that assures the management (Adams, 1994). The shareholder's interest has been reinforced through the efforts of professional bodies and government which result in increased demand for the management to ensure that corporations are managed effectively. Much of this demand has been as a result of public expectations in reaction to corporate scandals. The institutional theory postulates that a corporation's management and control arrangement tends to go with public expectations. Thus, this study relies on both the agency and institutional theories to compare the similarities and differences between public and private sectors IAF in Nigeria. 


\section{RESEARCH METHOD}

To speed-up, the analysis of the result data was gathered using a questionnaire sent to the head of internal audits of the sampled organizations. The sample comprises of both private and public-sector entities in Nigeria. Private sector entities comprise of 257 listed firms out of which 80 were selected as the final sample. The public sector in Nigeria comprises three tiers of government, namely: The Federal, State and Local Government Councils. The sample in this study comprises 40 federal public companies excluding federal ministries.

The questionnaires were hand delivered and sent as an email attachment with responses being received directly and as an email attachment to the researcher. The questionnaires were mailed to 120 head of internal audits, and 68 responses were received generating a response rate of 56.66 percent. There were 41 responses from the private sector organizations representing 60.29 percent and 27 responses representing 39.17 percent from the public sector.

The questionnaire was structured following previous studies with little modification (Goodwin 2003; Goodwin 2004; Arena \& Azzone 2007; Christopher et al., 2009; Messeir et al., 2011), each question was designed to incorporate responses expressed in multiple choices that enabled the respondents to express their opinion.

\section{RESULTS}

This section presents the results of the statistical analysis performed on data collected through the survey.

\subsection{Organizational Status of IAF}

Prior studies regarding the organizational status of IAF has centred on management support, independence, day-to-day reporting, IAF budget, objectivity, recruitment, training and dismissal and hierarchical rank of IAF (DeZoort, 2000; Glascock, 2002; James 2003; Smith, 2005 Zain et al. 2006; Mihret \& Yisman, 2007; Christopher et al. 2009; Ebaid, 2011). Internal audit is carried out in a setting close to management. Thus, its independence and objectivity from management are subject to question (Glascock, 2002). Leung et al. (2004) reported that majority of internal audit executives in Australian companies had reporting task to the board of directors or audit committees. Christopher et al. (2009) indicated a threat to internal audit independence when using IAF as a stepping stone to other positions having the CFO and CEO appropriating the IAF budget. Thus, Table 1 to Table 4 present the result of the organizational status of IAF of this study.

Table 1. Hierarchical Rank of IAF

\begin{tabular}{lcccc}
\hline \multirow{2}{*}{ Hierarchy of IAF } & \multicolumn{2}{c}{ Public Sector } & \multicolumn{2}{c}{ Private Sector } \\
\cline { 2 - 5 } & Frequency & Percentage & Frequency & Percentage \\
\hline Corporate level & 21 & 78 & 36 & 88 \\
Regional level & 6 & 22 & 5 & 12 \\
State level & - & - & - & - \\
\hline Total & $\mathbf{2 7}$ & $\mathbf{1 0 0}$ & $\mathbf{4 1}$ & $\mathbf{1 0 0}$ \\
\hline
\end{tabular}

Table 1 presents the results of the percentage test determining whether the hierarchical rank of IAF differs between the private and public-sector companies. The result shows that 36 internal audit managers in the private sector representing 88 percent indicated that the head of internal audit is located at corporate level compare to 21 respondents representing 78 percent in the public sector. This result suggests that IAF of both sectors was placed 
at the corporate level as opposed to being placed at the regional level or state level. This is in line with ISA 2007, SEC code of corporate governance and Financial Regulation Rules of the Federal Government Official Gazette 2009.

Table 2. Average Internal Auditor Stay in a Unit

\begin{tabular}{lcccc}
\hline \multirow{2}{*}{ Years } & \multicolumn{2}{c}{ Public Sector } & \multicolumn{2}{c}{ Private Sector } \\
\cline { 2 - 5 } & Frequency & Percentage & Frequency & Percentage \\
\hline Less than 2 years & - & - & 4 & 9.76 \\
$2-4$ years & - & - & 19 & 46.34 \\
$5-$ 6 years & - & - & 12 & 29.27 \\
$7-8$ years & 5 & 19 & 6 & 14.63 \\
More than 8 years & 22 & 81 & - & - \\
\hline Total & $\mathbf{2 7}$ & $\mathbf{1 0 0}$ & $\mathbf{4 1}$ & $\mathbf{1 0 0}$ \\
\hline
\end{tabular}

On the average number of years' internal auditors stay in a unit before being transferred to another unit within the company 46.34 percent from the private sector indicated an average of between 2-4 years, with 9.76 percent indicating less than 2 years. Whereas 81 percent of the respondents from the public sector indicated that on average internal auditors stays for more than 8 years in the IAF.

Table 3. IAF recruitment, training, and dismissal

\begin{tabular}{lcccc}
\hline IAF Recruitment, Training and & \multicolumn{2}{c}{ Public Sector } & \multicolumn{2}{c}{ Private Sector } \\
\cline { 2 - 5 } Dismissal & Frequency & Percentage & Frequency & Percentage \\
\hline Audit A/C & - & - & 9 & 23 \\
AC/CEO & - & - & 28 & 68 \\
CEO & 22 & 81.48 & 3 & 7 \\
CEO/CFO & 5 & 18.52 & 1 & 2 \\
\hline Total & $\mathbf{2 7}$ & $\mathbf{1 0 0}$ & $\mathbf{4 1}$ & $\mathbf{1 0 0}$ \\
\hline
\end{tabular}

Table 3 shows that 23 percent of respondents in the private sector indicated that Audit Committee (AC) members are involved in the appointment, evaluation, and dismissal of the head of the IAF while 68 percent indicated that audit committee performs these functions together with the Chief Executive Officer (CEO). Also, 81.48 percent of the respondents in the public sector indicated that the CEO was mandated to appoint, evaluate and dismiss the head of IAF.

Table 4. IAF day-to-day Reporting

\begin{tabular}{lcccc}
\hline \multirow{2}{*}{ IAF Day to Day Reporting } & \multicolumn{2}{c}{ Public Sector } & \multicolumn{2}{c}{ Private Sector } \\
\cline { 2 - 5 } & Frequency & Percentage & Frequency & Percentage \\
\hline Audit AVC & - & - & 5 & 12 \\
AC /CEO & - & - & 29 & 71 \\
CEO & 22 & 81.5 & 4 & 10 \\
CEO/CFO & 5 & 18.5 & 3 & 7 \\
\hline Total & $\mathbf{2 7}$ & $\mathbf{1 0 0}$ & $\mathbf{4 1}$ & $\mathbf{1 0 0}$ \\
\hline
\end{tabular}

Table 4 present the reporting relationship of the responding IAF. It shows that 71 percent of the private sector IAF report to the audit committee and CEO, while 10 percent indicates that besides the audit committee and CEO, they also report CEO. Table 4 further shows that 81.5 percent of the public-sector respondents indicated that IAF reports to CEO while 18.5 percent indicated that besides the CEO they also report to the CEO and CFO. 


\subsection{In Sourcing Versus Out Sourcing of Internal Audit Activities}

Several studies have investigated the insourcing versus outsourcing arrangements of IAF activities. For example, Lowe et al. (1999) indicated that internal audit outsourcing has a significant negative influence on the loan officer's opinion of auditor independence and financial statement reliability. Carey et al. (2006) reported that $45 \%$ of Australian companies had outsourced some of their internal audit activities. Similarly, Dickins and O'Reilly (2009) show that $77 \%$ of US middle-market companies have outsourced their IAF work. In a study of Arena and Azzone (2007) indicated that $69.41 \%$ of Italian companies do not outsource internal audit services. Thus table 5 and 6 present the result of IAF outsourcing of this study.

Table 5. Internal audit services outsourcing

\begin{tabular}{lcccc}
\hline \multirow{2}{*}{ IAF Services Outsourcing } & \multicolumn{2}{c}{ Public Sector } & \multicolumn{2}{c}{ Private Sector } \\
\cline { 2 - 5 } & Frequency & Percentage & Frequency & Percentage \\
\hline Yes & 18 & 67 & 35 & 85.37 \\
No & 9 & 33 & 6 & 14.63 \\
\hline Total & $\mathbf{2 7}$ & $\mathbf{1 0 0}$ & $\mathbf{4 1}$ & $\mathbf{1 0 0}$ \\
\hline
\end{tabular}

Table 5 shows that there was a slight difference between the two sectors of internal audit service outsourcing. The result shows that 85.37 percent of the private sector IAF was involved in outsourcing compared to 67 percent of the public sector. With regards to the nature of internal audit services outsourced the result is presented in Table 6.

Table 6. Internal audit services outsourced

\begin{tabular}{lcccc}
\hline \multirow{2}{*}{ IAF Services Outsourced } & \multicolumn{2}{c}{ Public Sector } & \multicolumn{2}{c}{ Private Sector } \\
\cline { 2 - 5 } & Frequency & Percentage & Frequency & Percentage \\
\hline Compliance audit & 6 & 22.22 & 14 & 34.14 \\
Financial audit & 19 & 70.37 & 19 & 46.34 \\
Operational audit & 2 & 7.41 & 5 & 12.20 \\
Environmental audit & - & - & 3 & 7.32 \\
\hline Total & $\mathbf{2 7}$ & $\mathbf{1 0 0}$ & $\mathbf{4 1}$ & $\mathbf{1 0 0}$ \\
\hline
\end{tabular}

On the nature/type of audit services outsourced, the result of the study revealed that financial audit rank as the most frequently outsourced service with 46.34 percent of the private sector and 70.37 percent of the public-sector outsourcing. Compliance audit was outsourced by 34.14 percent of private sector and22.22 percent of the public sector, while environmental audit consists of 7.32 percent of private sector outsourcing and 10 percent of that in the public sector.

\subsection{Internal Auditor Interaction with External Auditor}

There is extensive literature on the relations between external and internal auditors. Most of the previous studies investigating the relationship between external and internal auditors centred on the extent of reliance of external auditor on the work of internal auditor and the consequences of this reliance (Maletta, 1993; Braody, 1998; Felix et al, 2001; Krishnamoorrthy, 2002; Al-Twaijry, 2004; Golver et al, 2008; Suwaidan and Qasim, 2010; Prewitt et al, 2011). The results of these studies show that the reasons for this reliance are the competence of the internal auditor, objectivity, independence, and quality of work carried out. Thus, table $7-9$ present the result of IAF interaction with the external auditor for this study. 
Table 7. External and internal auditor coordination in the area of audit coverage

\begin{tabular}{lcccc}
\hline Coordination in the Area of & \multicolumn{2}{c}{ Public Sector } & \multicolumn{2}{c}{ Private Sector } \\
\cline { 2 - 5 } Audit Coverage & Frequency & Percentage & Frequency & Percentage \\
\hline Yes & 18 & 67 & 36 & 89 \\
No & 9 & 33 & 5 & 11 \\
\hline Total & $\mathbf{2 7}$ & $\mathbf{1 0 0}$ & $\mathbf{4 1}$ & $\mathbf{1 0 0}$ \\
\hline
\end{tabular}

On coordination of work of IAF and external auditor access to working papers, the results revealed that there is no much difference between private sector and public sector. More than two third of the IAF co-ordinate in the areas of audit coverage with the external auditor, and additionally, in both sectors, external auditors have a high level of access to internal audit working papers.

Table 8. External auditor access to IAF working papers

\begin{tabular}{lcccc}
\hline External auditor access to IAF & \multicolumn{2}{c}{ Public Sector } & \multicolumn{2}{c}{ Private Sector } \\
\cline { 2 - 5 } working papers & Frequency & Percentage & Frequency & Percentage \\
\hline Yes & 16 & 59 & 33 & 80 \\
No & 11 & 41 & 8 & 20 \\
\hline Total & $\mathbf{2 7}$ & $\mathbf{1 0 0}$ & $\mathbf{4 1}$ & $\mathbf{1 0 0}$ \\
\hline
\end{tabular}

Table 8 presents an overview of external auditor access to IAF working papers. The results showed that both sectors have a high level of access to internal audit working paper. The results indicated that both sectors have a higher level of access to internal audit working papers.

Table 9. Impact of IAF on the cost of an external audit

\begin{tabular}{lcccc}
\hline Impact of IAF cost on external & \multicolumn{2}{c}{ Public sector } & \multicolumn{2}{c}{ Private sector } \\
\cline { 2 - 5 } audit & Frequency & Percentage & Frequency & Percentage \\
\hline Less than $10 \%$ & 7 & 25.93 & 14 & 34.15 \\
$10-20 \%$ & 16 & 59.26 & 21 & 51.22 \\
$21-30 \%$ & 4 & 14.81 & 6 & 14.63 \\
\hline Total & $\mathbf{2 7}$ & $\mathbf{1 0 0}$ & $\mathbf{4 1}$ & $\mathbf{1 0 0}$ \\
\hline
\end{tabular}

Table 9 shows the impact of the auditor reliance on the internal audit on the cost of the external audit. In the private sectors, 51.22 percent of the respondents agreed that the cost reduction is higher between 10 to 20 percent of audit fees compared to 59.26 percent in the public sector.

\section{DISCUSSION}

IAF plays a critical position in corporate governance by providing a range of consulting and assurance services. To be effective, IAF should be given the right place in the organization to enable it to exercise objectivity and independence. The Institute of Internal Auditors (IIA, 2001) emphasized the significance of organizational independence and objectivity of IAF, with the head of the internal audit reporting to a level within the organization that allows the function to achieve its obligations. The study examines the similarities and differences between private sector internal audit function and that of its counterpart in the public sector.

The result of the study reveals that a large number of Nigerian public and private companies established IAF. The result of the percentage test determining whether the hierarchical rank of IAF differs between the private and public-sector companies shows that 88 percent of the private sector respondent indicated that the head of the IAF is located at corporate level compares to 78 percent in the public sector. These findings are 
corroborated with those that have been documented in the prior literature. For example, Christopher et al. (2009) find that both private and public-sector entities IAF head in Australian were placed at the corporate level.

On the average number of years internal auditor stays in a unit before being transfer to another unit within the company, 46.34 percent from the private sector indicated that an average of 2-4 years with 9.76 percent indicating less than 2 years. Whereas 81 percent of the respondent from the public sector indicated that on average internal auditor stays for more than 8 years in the IAF unit. Christopher et al. (2009) reported that 47 percent of the respondents indicate that on average internal auditors in Australia stay 2 and 4 years in IAF unit. A similar study by Goodwin and Yeo, (2001) indicated that 37 percent (20 respondents) shows that in IAF such a movement to other units was unlikely for internal auditors in Singapore.

With respect to recruitment, training and dismissal of internal auditor 23 percent of respondent in the private sector indicated that audit committee (AC) members are involved in the appointment, evaluation, and dismissal of the head of IAF while 68 percent indicated that audit committee performs these functions together with the chief executive officer (CEO). Also, 81.48 percent of the respondents in the public sector indicated that the CEO is mandated to appoint, evaluate and dismiss the head of IAF. In a study conducted in Canada by Scarbrough et al. (1998), it was reported that 48 percent of the respondents shows that the audit committee was involved in the dismissal of the head of IAF. Goodwin and Yeo (2001) reported 72 percent in Singapore, whereas Goodwin, (2003) reported that 50 percent of audit committee members were involved in the appointment, evaluation, and dismissal of internal audit head in Australia.

Day-to-day reporting relationship of IAF shows that 71 percent of the private sector respondent indicated that IAF report to the audit committee and CEO while 10 percent indicated that besides audit committee and CEO they also report to the chief financial officer (CFO). The result further reveals that 81.5 percent of the public-sector respondents indicated that IAF reports to CEO while 18.5 percent indicates that besides the CEO they also report to CEO and CFO. In a similar study, Christopher et al. (2009) indicated that 38 percent of the IAF report functionally to the AC, 47 percent indicated that besides the audit committee they also report functionally to CEO and CFO whereas 32 percent of the respondents reported that IAF reports administratively to CEO.

On the nature of audit services outsourced, the result of the study shows a difference between the two sectors with regard. 85.37 percent of the private sector IAF was involved in outsourcing compared to 67 percent of the public sector. This study is inconsistent with that of Arena and Azzone (2007) which indicated that 69.41 percent of Italian companies do not outsource internal audit services. However, consistent with that of Goodwin (2004) which shows that 68 percent of public sector firms and 65 percent of private sector firms engaged in outsourcing internal audit services.

With regards to the nature of internal audit services outsourced, the result of the study revealed that financial audit rank as the most frequently outsourced service with 46.34 percent of the private sector and 70.37 percent of the public sector. Compliance audit was outsourced by 34.14 percent of the private sector and 22.22 of the public sector, while environmental audit comprises of 7.32 percent of the private sector. In a related study, Christopher et al. (2009) reported information technology and system rank as the most commonly outsourced service with 45 percent of the public sector and 50 percent of private sector whereas performance audit comprises of 7 percent of the public sector and 8 percent of private sector outsourcing in Australia and New Zealand.

On the coordination of IAF and external auditor access to internal audit working papers, the results revealed that there is no much difference between the private and public sector. More than two third of the IAF coordinate in the areas of audit coverage with 
the external auditor and additionally, on both sectors external auditors have a high level of access to internal audit working papers. External auditing standards inspire external auditors to lessen the amount of work they carry out by relying on the effort of internal auditors (AICPA 1990). Empirical evidence has also shown that increased reliance on the work of IAF can reduce the cost of external audit fees (Felix et al. 2001; Gramling et al. 2004; Prawitt et al. 2011).

The results of the impact of IAF on the cost of the external audit revealed that 5.22 percent of the private sector respondents agree that the cost reduction is higher between $10-20$ percent of audit fees compared to 59.26 percent in the public sector. Empirical evidence, for example, Hogan and Wikkins (2006) and Beneish et al. (2006) reported an increased in external audit fees due to IAF reporting requirements of SOX. Furthermore, Messier et al. (2011) indicated that using IAF as a management training ground influence external audit fees which they provide evidence that external auditors perceived internal auditors in an IAF used as management training ground to be less objective than internal auditors employed in an IAF not used as management training ground.

\section{CONCLUSION}

This study examines the similarities and differences of private sector IAF and that of its counterpart in the public sector using data collected from Nigeria companies. The study is based on a survey of internal audit managers and chief internal auditors in Nigeria. The results revealed that private sector IAF and its counterpart in the public sector have a higher hierarchal ranking where two-thirds of the internal audit managers and chief internal auditors indicated that IAF was placed at the corporate level. Whereas less than half of the respondents in the private sector indicated that internal auditors stay between two to four years in the IAF with more than half of the public-sector respondent indicating internal auditors stays for more than 8 years in the unit.

It was also found that more than half (68 percent) of the private sector respondents indicated that both the audit committee and CEO were involved in the appointment, evaluation and dismissal of the head of internal audit unit while 81.48 percent of the public sector indicated that CEO is mandated to appoint, evaluate and dismiss the head of the internal audit unit. The results also showed that 85.37 percent of private sector entities and 67 percent of public sector IAF indicated that they engaged in outsourcing of internal audit services. Whereas financial audit rank as the most frequently outsourced services in both two sectors.

However, with other researchers, this study also had potential limitations which provide avenues for further research. Firstly, consistent with the general trends in questionnaire-based research the limited number of respondents could be a hindrance to the generalization of the results and the study does not cover private companies (unlisted) thereby require careful interpretation of the findings. Secondly, the respondents were not asked directly, and this may cause misinterpretation of response because the instrument prevents the possibility of explaining and detailing the questions and there is direct control over the actual respondents.

Finally, this study has higher-lighted the issue of IAF in private and public sector entities in Nigeria. There is increasing attention towards internal auditing and that companies make different choices concerning issues regarding organizational structures and resource management. In the light of these future studies could address the problems of the effectiveness of IAF, independence, relationship with the audit committee and management, the role of IAF in strengthening financial reporting quality, and if companies are investing increasing efforts in developing IAF. 


\section{REFERENCES}

Abbott, L.J., Parker, S., \& Rama, D.V. (2007). Corporate governance, audit quality, and the Sarbanes- Oxley Act: Evidence from internal audit outsourcing. The Accounting Review, 82(4): 803-835.

Adams, M.B. (1994). Agency theory and internal audit. Managerial Auditing Journal, 9(8): 8-12

Al-Twaijry, A.A., Brierley, J.A., \& Gwilliam, D.R. (2004). An examination of the relationship between internal and external audit in the Saudi Arabian corporate sector. Managerial Auditing Journal, 19(7), 929-944.

American Institute of Certified Public Accountants (AICPA). (1990). The Auditor's Consideration of the Internal Audit Function in an Audit of Financial Statements. Statement on Auditing Standards No. 65. New York, NY: AICPA.

Arena, M., \& Azzone, G. (2007). Internal audit departments: adoption and characteristics in Italian companies. International Journal of Auditing, 11, 91-114.

Arena, M., \& Azzone, G. (2009). Identifying organizational drivers of internal audit effectiveness. International Journal of Auditing, 13, 43-60.

Badara, M.S, \& Saidin, S.Z. (2014). Empirical evidence of the moderating effect of the effective audit committee on audit experience in the public sector: Perception of internal auditors. Mediterranean Journal of Social Sciences, 5(10), 176-184

Barac, K., \& Staden, M. V. (2014). Internal auditing as a corporate governance mechanism. A comparison between public sector and private sector functions. African Journal of Public Policy, 7(3), 17-31.

Beneish, M. D, Billings, N.B \& Hodder L.D. (2006). Internal control weaknesses and information uncertainty. Working paper, Indiana University.

Brody, R.G., Golen, S.P. \& Reckers, P.M. (1998). An empirical investigation of the interface between internal and external auditors. Accounting \& Business Research, 28(3), 160- 171.

Caplan, D.H., \& Kirschenheiter, M. (2000). Outsourcing and audit risk for internal audit services. Contemporary Accounting Research, 17(3), 387-428.

Carcello, J. V., Hermanson, D. R., \& Raghunandan, K. (2005). Changes in internal auditing during the time of the major US accounting scandals. International Journal of Auditing. 9(2), 117-27.

Carhill, K.M., \& Kincaid, J.K. (1989). Applying the standards in governmental internal auditing. The Internal Auditor, 46(5), 50-59

Carey, P., Subramaniam, N., \& Ching, K. (2006). Internal audit outsourcing in Australia. Accounting and Finance, 46(1), 11-30.

Christoper, J., Sarens, G., \& Lueng P. (2009). A critical analysis of the independence of the internal audit function: evidence from Australia. Accounting Auditing and Accountability Journal, 22(2), 200-220.

Coupland, D. (1993). The internal auditor's role in public service orientation. Managerial Auditing Journal, 8(1), 3-13.

DeFond, M.L., \& Francis, J.R. (2006). Audit research after Sarbanes-Oxley. Auditing: A Journal of Practice and Theory, 24, 5-30.

DeZoort, F., Houston, R., \& Reisch, J. (2000). Incentive compensation for internal auditors. Internal Auditor, 57(3), 42-46.

Dickins, D. \& O'Reilly, D. (2009). The qualifications and independence of internal auditors. Internal Auditing, 24(3), 14-21.

Emmanuel, O., \& Usman, H. (2015). Internal audit techniques and fraud prevention: A case study of selected local government councils in Bauchi state. Mediterranean Journal of Social Sciences, 6(4), 232-244.

Felix, W. L., Gramling, A.A., \& Maletta M.J. (2001). The contribution of internal audit as a determinant of external audit fees and factors influencing this contribution. Journal of Accounting Research, 39(3), 513-534.

Glascock, K. (2002). Auditees or clients? The Internal Auditor, 59(4), 84-85.

Glover, S., Prawitt, D., \& Wood, D. (2008). Internal audit sourcing arrangement and the external auditor's reliance decision. Contemporary Accounting Research, 25(1), 193- 213.

Goodwin, J. (2004). A comparison of internal audit in the private sector and public sectors. Managerial Auditing Journal, 19(5), 640-650. 
Goodwin, J., \& Yeo, T. Y. (2001). Two factors affecting internal audit independence and objectivity: evidence from Singapore. International Journal of Auditing, 5(2), 107-125.

Goodwin, J. (2003). The relationship between the audit committee and the internal audit function: Evidence from Australia and New Zealand. International Journal of Auditing, 7(3), 263-78.

Gramling, A. A., Maletta, M. J., Schneider, A., \& Church. B. K. (2004). The role of the internal audit function in corporate governance: A synthesis of the extant internal auditing literature and directions for future research. Journal of Accounting Literature, 23, 194- 244.

Hogan, C. E., \& Wilkins, M. S. (2006). Evidence on the audit risk model: Do auditors increase audit effort in the presence of internal control weaknesses. Working paper, Southern Methodist University.

Ima, J. N. (2015). Effective internal audit as a tool for fraud deterrence in Nigerian Organizations. Humanity and Social Sciences Journal, 10(2), 73-80.

International Federation of Accountants (IFAC) (2009). International Standard on Auditing Using the Work of Internal Auditors. International Auditing and Assurance Standards Board ISA 610. New York, NY: IFAC.

James, K. (2003). The effect of internal audit structure on perceived financial statements fraud prevention. Accounting Horizons, 17(4): 315-27.

Leung, P., Cooper, B. J., \& Robertson, P. (2004). Role of Internal Audit in Corporate Governance and Management, RMIT University, Melbourne.

Lowe, D., Geiger, M., \& Pany, K. (1999). The effects of internal audit outsourcing on perceived external auditor independence. Auditing: A Journal of Practice \& Theory, 18, 7-26.

Maletta, M. (1993). An examination of auditors' decision to use internal auditors as assistants: the effect of inherent risk. Contemporary Accounting Research, 9(2), 508-525.

Messier Jr., W. F., Reynolds J. K., Simon C.A., \& Wood D.A. (2011). The effect of using the internal audit function as management training ground on the external auditor's reliance decision. The Accounting Review, 86(6), 2131- 2154.

Modibbo, S.A. (2015). An assessment of the effectiveness of the internal audit unit at local government level in Adamawa state. International Journal of Humanities and Social Science, 54(1), 59-65.

Mihret, D., \& Yismaw, A. (2007). Internal audit effectiveness: an Ethiopian public sector case study. Managerial Auditing Journal, 22(5), 470-484.

Paape, L., Scheffe, J., \& Snoep, P. (2003). The relationship between the Internal Audit function and corporate governance in the EU - a survey. International Journal of Auditing, 7(3), 24762.

Patterson E. R., \& Smith J. R, (2007). The effect of Sarbanes-Oxley on auditing and internal control strength. The Accounting Review, 82(2), 427-455.

Prawitt, D. F., Sharp, N. Y., \& Wood D. A. (2011). Internal audit outsourcing and the risk of misleading or fraudulent financial reporting: Did Sarbanes-Oxley get it wrong? Working paper, Brigham Young University, Texas A\&M, and Brigham Young University.

Public Company Accounting Oversight Board (PCAOB) (2007). An Audit of Internal Control over Financial Reporting That Is Integrated with an Audit of Financial Statements. Auditing Standard No. 5. PCAOB Release No. 2007-005A. June 12. Washington, D.C.: PCAOB.

Ramamoorthi, S. (2003). Internal auditing: history, evolution, and prospects. The Institute of Internal Auditors Research Foundation, Altamonte Springs, FL.

Ruud, T.F. (2003). The internal audit function: An integral part of organizational governance. The Institute of Internal Auditors Research Foundation, Altamonte Springs, FL.

Sarens, G., \& De Beelde (2006). The relationship between internal audit and senior management: A qualitative analysis of expectations and perceptions. International Journal of Auditing, 10, 219-214

Scarbrough, D. P., Rama, D. V., \& Raghunandan, K. (1998). Audit committee composition and interaction with internal auditing: Canadian evidence. Accounting Horizons, 12(1), 51-62.

Schneider, A. (1984). Modelling external auditors' evaluations of internal auditing. Journal of Accounting Research, 22(2), 657-678.

Scott, W.R. (1987). The adolescence of institutional theory. Administrative Science Quarterly, 32(4), 493-511. 
Selim, G., \& Yiannakas, A. (2000), Outsourcing the internal audit function: A survey of the UK public and private sectors. International Journal of Auditing, 4(3), 213-260.

Smith, G. (2005). Communication skills are critical for internal auditors. Managerial Auditing Journal, 20(5), 513-539.

Zain, M. M., Subramaniam, N., \& Stewart, J. (2006). Internal auditors' assessment of their contribution to financial statement audits: the relation with the audit committee and internal audit function characteristics. International Journal of Auditing, 10(1), 1-18. 